\title{
Inducing salt tolerance in wheat through inoculation with rhizobacteria containing 1-aminocyclopropane-1- carboxylate deaminase activity
}

\author{
Muhammad Arshad Ullah ${ }^{1 *}$, Syed Ishtiaq Hyder ${ }^{1}$, Imdad Ali Mahmood ${ }^{1}$, \\ Tariq Sultan ${ }^{1}$ and Lal Badshah ${ }^{2}$
}

${ }^{1}$ Land Resources Research Institute, National Agricultural Research Centre, Park Road, Islamabad-45500, Pakistan. ${ }^{2}$ Department of Microbiology Faculty of Health Sciences, Hazara University, Mansehra, KPK, Pakistan.

${ }^{*}$ Corresponding author. Email: arshad_pak786@yahoo.com

Copyright ( 2017 Arshadullah et al. This article remains permanently open access under the terms of the Creative Commons Attribution License 4.0, which permits unrestricted use, distribution, and reproduction in any medium, provided the original work is properly cited.

Received 23rd June, 2017; Accepted 12th July 2017

\begin{abstract}
Wheat (Triticum aestivum) is the fundamental feed of people as it contributes $60 \%$ of the daily diet of ordinary man in Pakistan. Salinity is one of the most imperative stresses that hinder agricultural productivity in nearly every part of the world. Improved biosynthesis of ethylene in plants under salinity stress is well established. Higher ethylene concentration retards root growth and eventually disturbs the overall plant growth. Plant growth promoting Rhizobacteria (PGPR) emits 1-aminocyclopropane-1-carboxylate (ACC) deaminase action under salt stressed conditions which minimizes the power of $A C C$ and ethylene justifying the lethal effects of salt stress on plant growth. The seeds inoculated with PGPR having ACC deaminase are comparatively more tolerant to salt stress. The study was conducted at National Agriculture Research Centre Islamabad to examine the influence of PGPR on wheat growth (cultivars Pak-13 NARC-11 and NARC-09) and ionic concentration under saline environment to see the impact of bacterial strains having ACC deaminase on wheat growth and ionic concentration. The experiment was set up following completely randomized design with three repeats. Wheat seeds were inoculated following rhizobacteria strains, WPR61, WPR-51, WPS-09 and Consortium of WPR-61, WPR-51 and WPS-09. Salinity (10.62dS m-1) was artificially developed using salts. Shoot and root length significantly affected by different rhizobial strains. The maximum root and shoot length attained by the consortium of three strains. The best results were achieved on NARC-09 wheat variety.Pak13 wheat variety was significant affected by different rhizobial strains and maximum phosphorus concentration attained by WPS-09 strain in Pak-13.
\end{abstract}

Keywords: Ethylene, rhizobial strains, salinity, salt tolerance, wheat cultivars, wheat growth.

\section{INTRODUCTION}

The entire form of life is reliant on plants as they produce oxygen and form the staple food for humans and animals. According to report, $98 \%$ of the world's food necessities are fulfilled by 12 plant species and 14 animal species. Above $50 \%$ of the world energy ingestion is met by crops such as wheat, rice and maize (Thrupp, 2000).

Soil salinity is one of the chief abiotic factors affecting soil microbial activities and crop productivity. Reports showed that over $20 \%$ of agricultural land internationally is affected by salt (Pitman and Läuchli, 2002). It is estimated that the salinization will cause the loss of $50 \%$ arability of agricultural land by the middle of the $21 \mathrm{st}$ century (Wang et al., 2003). Saline soil adversely retards the plant growth and productivity by shifting the normal metabolism of plants. Mitigation of salinity stress by plant growth promoting rhizobzcteriain plants. One of the effects of salt stress is an increase in the band of 1aminocyclopropane-1-carboxylic acid (ACC), a precursor of ethylene, which consequences in accretion of ethylene. Increase in the rank of ethylene away from a 
threshold level is termed 'stress ethylene', which minimizes plant growth (Penrose and Glick, 2003) and alters photosynthesis and photosynthetic components (Koryo, 2006). Besides salt stress, other stresses such as flood, drought, wounding, pathogen attack, temperature stress, and mechanical stress also contribute to considerable rise in the level of endogenous 'stress ethylene' (Stearns and Glick, 2003).

A large number of microorganisms live in a little bit of soil that is adapted or inclined by plant roots, called rhizosphere (Selosse et al., 2004). Useful bacteria can fasten to the roots or leaves of plants and thus are referred to as rhizosphere and phyllosphere bacteria respectively. They may also survive in the tissues of plant (endophyte bacteria) (Glick et al., 2007). Soil microorganisms play major role in the continuation of soil health (Jeffries et al.2003). Nakbanpote et al. (2013) reported salt-tolerant and plant growth-promoting bacteria isolated from $\mathrm{Zn} / \mathrm{Cd}$ polluted soil.

Definite growth changes occur in the root system of the host due to colonization of the rhizosphere soil by rhizobacteria (German et al., 2000). These free-living rhizobacteria can be used in a number of ways when plant growth promotion is required (Lucy et al., 2004). The outcome of PGPR on agricultural crops has been investigated and published by various scientists during the last two decades (Asghar et al., 2002; Khalid et al., 2003; Asghar et al., 2004; Khalid et al., 2004; Zahir et al., 2004). The capability of these strains for improving plant growth was tested in agriculture by using bacterial inoculation in greenhouse as well as under natural field conditions (Salamone, 2000; Bent et al., 2001; Shaharoona et al., 2007, 2008).

Ethylene is a simple, two-carbon, unsaturated hydrocarbon which is a potent regulator of plant growth and progress (Binder, 2008). Initially, ethylene was known as a ripening hormone, but later demanding studies, tied with the advent of highly sophisticated analytical techniques, like gas chromatography, unveiled its role in growth and development all over the life cycle of the plant. On account of its varied and effectual role in plant growth and development, ethylene virtues equal category with other classes of plant hormones (Arshad and Frankenberger, 2002). Therefore, this study was planned at National Agriculture Research Centre Islamabad to examine the consequence of PGPR on wheat cultivars (Pak-13 NARC-11 and NARC-09) under saline environment.

\section{MATERIALS AND METHODS}

The wheat seeds of three cultivars namely Pak-13, NARC-11 and NARC-09 were inoculated with PGPR (WPR-61, WPR-51, WPS-09 and Consortium of WPR-61, WPR-51 and WPS-09) having ACC deaminase. The study was conducted at National Agriculture Research
Table1. Physiochemical analysis of soil used in the experiment.

\begin{tabular}{llc}
\hline Characteristics & Unit & Values \\
\hline $\mathrm{pH}$ & - & 7.02 \\
Electrical conductivity & $\left(\mathrm{dS} \mathrm{m}^{-1}\right)$ & 10.62 \\
Organic Matter & $(\%)$ & 0.49 \\
$\mathrm{Na}$ & $\mathrm{ppm}$ & 310 \\
$\mathrm{~K}$ & $\mathrm{ppm}$ & 42 \\
$\mathrm{P}(\mathrm{AB}-\mathrm{DTPA})$ & $\mathrm{ppm}$ & 0.51 \\
Ca+Mg & $(\mathrm{meq} / \mathrm{L})$ & 24 \\
Carbonate & $(\mathrm{meq} / \mathrm{L})$ & 0.6 \\
Bicarbonate & $(\mathrm{meq} / \mathrm{L})$ & 0.20 \\
SAR & meq/L) & 10.75 \\
Soil type & - & Sandy Loam \\
\hline
\end{tabular}

Centre Islamabad to examine the consequence of PGPR on wheat cultivars (Pak-13 NARC-11 and NARC-09) under saline environment to see the impact of bacterial strains on ACC deaminase on wheat growth and ionic concentration. The design was completely randomized, factorial with three repeats. Wheat seeds were inoculated with rhizobacteria strains which were: WPR-61, WPR-51, WPS-09 and Consortium of WPR-61, WPR-51 and WPS09 . Salinity $\left(10.62 \mathrm{dS} \mathrm{m}^{-1}\right)$ was artificially developed using salts (Table 1). A soil sample (0 to $20 \mathrm{~cm}$ depth) was collected from experimental area before sowing of crop and fertilizers application. Plant samples were collected to see the effect of different rhizobial strains on the availability of nutrients to plants after two months. Soil samples were analyzed for various physicochemical properties using standard methods (Ryan et al., 2001; Sparks et al., 1996) and soil texture by Bouyoucous Hydrometer method (Kanwar and Chopra, 1959). The data obtained were subjected to statistical analysis using the STATISTIX statistical software (Version 8.1) and the mean values were compared using least significant difference (LSD) (Steel and Torrie, 1997).

\section{RESULTS AND DISCUSSION}

Shoot length was drastically affected by the inoculation wheat seeds with different rhizobial strains under artificially developed saline soil $\left(E C e=10.62 \mathrm{dS} \mathrm{m} \mathrm{m}^{-1}\right)$ (Table 2). The highest shoot length $(16.3 \mathrm{~cm})$ was observed by inoculating with the consortium of three strains which was statistically at par with the results attained with WPS-8 and lowest shoot length $(5.3 \mathrm{~cm})$ was observed in control (without inoculation). This indicated that inoculation of wheat seed with rhizobial strains showed better responses in shoot length mitigating the adverse effects of saline conditions $\left(\mathrm{ECe}=10.62 \mathrm{dS} \mathrm{m}^{-1}\right)$. Varietal differences regarding shoot length was very minute as indicated in Table 2. Similar 
Table 2.The effect of ACC deaminase on Shoot / root length and Plant fresh/dry weight of Wheat varieties (Pak-13, NARC11 and NARC-09).

\begin{tabular}{|c|c|c|c|c|c|c|c|c|c|c|c|c|}
\hline \multirow[t]{2}{*}{ Treatments } & \multicolumn{3}{|c|}{$\begin{array}{l}\text { Shoot Length } \\
\left(\mathrm{cm} \text { plant }{ }^{-1}\right)\end{array}$} & \multicolumn{3}{|c|}{$\begin{array}{c}\text { Root Length } \\
\left(\mathrm{cm} \text { plant }{ }^{-1}\right)\end{array}$} & \multicolumn{3}{|c|}{$\begin{array}{c}\text { Plant fresh weight } \\
\left.\left(\text { g plant }^{-1}\right)\right)\end{array}$} & \multicolumn{3}{|c|}{$\begin{array}{c}\text { Plant dry weight } \\
\left.\text { (g plant }{ }^{-1}\right)\end{array}$} \\
\hline & $V_{1}$ & $\mathrm{~V}_{2}$ & $V_{3}$ & $\mathrm{~V}_{1}$ & $V_{2}$ & $V_{3}$ & $\mathrm{~V}_{1}$ & $V_{2}$ & $\mathrm{~V}_{3}$ & $V_{1}$ & $V_{2}$ & $V_{3}$ \\
\hline$T_{1}$ & $5.9 c$ & $5.4 \mathrm{c}$ & $5.3 c$ & $6.8 \mathrm{~b}$ & $6.6 b$ & $6.7 b$ & $1.0 \mathrm{~b}$ & $1.1 \mathrm{~b}$ & $1.2 \mathrm{~b}$ & $0.5 b$ & $0.5 b$ & $0.6 \mathrm{~b}$ \\
\hline $\mathrm{T}_{2}$ & $8.9 b$ & $8.1 b$ & $8.3 b$ & $9.1 \mathrm{a}$ & $9.3 a$ & $9.9 a$ & $1.8 \mathrm{a}$ & $1.7 a$ & $1.9 a$ & $0.9 a$ & $0.8 a b$ & $0.9 a$ \\
\hline $\mathrm{T}_{3}$ & $10.8 b$ & $10.0 \mathrm{~b}$ & $10.7 \mathrm{~b}$ & $9.6 a$ & $9.0 a b$ & $9.0 \mathrm{ab}$ & $2.3 a$ & $2.4 a$ & $2.3 a$ & $1.1 \mathrm{a}$ & $1.2 \mathrm{a}$ & $1.3 a$ \\
\hline $\mathrm{T}_{4}$ & $12.5 \mathrm{a}$ & $13.2 \mathrm{a}$ & $12.7 \mathrm{a}$ & $11.1 \mathrm{a}$ & $11.3 a$ & $11.2 \mathrm{a}$ & 2.3a & $2.5 \mathrm{a}$ & $2.4 a$ & $1.2 \mathrm{a}$ & 1. $1 \mathrm{a}$ & $1.3 \mathrm{a}$ \\
\hline $\mathrm{T}_{5}$ & $15.7 \mathrm{a}$ & $16.2 \mathrm{a}$ & $16.3 a$ & $12.9 a$ & $13.3 a$ & $12.7 \mathrm{a}$ & $2.5 \mathrm{a}$ & $2.4 a$ & $2.5 \mathrm{a}$ & $1.3 a$ & $1.2 \mathrm{a}$ & $1.3 a$ \\
\hline LSD (0.5\%) & & 5.1 & & & 4.2 & & & 0.9 & & & 0.5 & \\
\hline
\end{tabular}

Values followed by same letter(s) are statistically similar at $P=0.05$ level of significance. $P a k-13=V_{1} N A R C-11=V_{2} N A R C-09=V_{3} ;$ Means $=$ $\mathrm{M}, \mathrm{T} 1=$ Control, $\mathrm{T}_{2}=$ WPR-61, $\mathrm{T}_{3}=\mathrm{WPR}-51, \mathrm{~T}_{4}=$ WPS-09, $\mathrm{T}_{5}=$ Consortium of WPR-61, WPR-51 and WPS-09.

Table 3. The effect of ACC deaminase on the Phosphorus concentration (\%) of three wheat varieties (Pak-13, NARC11 and NARC-09).

\begin{tabular}{lccc}
\hline Treatments & $\mathbf{V}_{\mathbf{1}}$ & $\mathbf{V}_{\mathbf{2}}$ & $\mathbf{V}_{\mathbf{3}}$ \\
\hline $\mathrm{T}_{1}$ & $0.08^{\mathrm{f}}$ & $0.09^{\mathrm{e}}$ & $0.07^{\mathrm{f}}$ \\
$\mathrm{T}_{2}$ & $0.09^{\mathrm{e}}$ & $0.09^{\mathrm{e}}$ & $0.07^{\mathrm{f}}$ \\
$\mathrm{T}_{3}$ & $0.15^{\mathrm{c}}$ & $0.14^{\mathrm{d}}$ & $0.14^{\mathrm{d}}$ \\
$\mathrm{T}_{4}$ & $0.20^{\mathrm{a}}$ & $0.18^{\mathrm{b}}$ & $0.14^{\mathrm{d}}$ \\
$\mathrm{T}_{5}$ & $0.17^{\mathrm{b}}$ & $0.16^{\mathrm{c}}$ & $0.15^{\mathrm{c}}$ \\
$\mathrm{LSD}(0.5 \%)$ & & 0.02 & \\
\hline
\end{tabular}

Values followed by same letter(s) are statistically similar at $\mathrm{P}=0.05$ level of significance. Pak $-13=\mathrm{V}_{1}$, NARC-11 $=\mathrm{V}_{2}$, NARC$09=\mathrm{V}_{3}, \mathrm{~T}_{1}=$ Control, $\mathrm{T}_{2}=$ WPR $-61, \mathrm{~T}_{3}=$ WPR-51, $\mathrm{T}_{4}=$ WPS -09 , $\mathrm{T}_{5}=$ Consortium of WPR-61, WPR-51 and WPS-09.

trend was also noted in root length (Table 2). Significant results were achieved in plant fresh weight of three wheat varieties inoculated with strains under saline environment $\left(E C e=10.62 \mathrm{dS} \mathrm{m}^{-1}\right)$ as shown in Table 2. Maximum fresh weight $\left(2.5 \mathrm{~g} \mathrm{plant}^{-1}\right)$ was attained with the consortium of three strains which was statistically at par with the results attained with WPS-8 and lowest shoot length (1.0 g plant 1) was noted in control (without inoculation). This indicated that inoculation of wheat seed with rhizobial strains showed better responses in plant fresh weight extenuating the adverse effects of saline conditions $\left(E C e=10.62 \mathrm{dS} \mathrm{m}^{-1}\right)$. Varietal differences regarding plant fresh weight was very minute as shown in Table 2. Similar trend was also noted in plant dry weight (Table 2). Many researchers have studied better performance in plant growth inoculated with rhizobial bacterial containing ACC-deaminase (Mayak et al., 2004; Shaharoona et al., 2006). Ethylene is a stress hormone and is produced at higher concentration under any kind of stress including salinity. It is very liable that the rhizobacterial strains promoted root and shoot growth by lowering the endogenous inhibitory levels of ethylene in roots because of its high ACC metabolizing ability (Kang et al., 2010).
Ionic concentration of $\mathrm{P}(\%)$ in wheat plants showed significant differences among treatments (Table 3 ). Uptake of P (\%) was more $(0.20 \%)$ by WPS-8 and control showed the lowest $(0.07 \%)$. Singh et al. (2013) reported that judicious use of chemicals along with bio fertilizers and organic resources can be helpful in sustaining the crop productivity and soil health.

\section{Conclusion}

Shoot and root length significantly affected by different rhizobial strains. The maximum root and shoot length attained by the consortium of three strains. NARC-09 showed the best results of root and shoots length among the wheat varieties. Pak-13 wheat variety was significantly affected by different rhizobial strains and maximum phosphorus concentration attained by WPR-61 strain was in Pak-13.

\section{CONFLICT OF INTEREST}

The authors declare that they have no conflict of interest.

\section{REFERENCES}

Arshad, M., \& Frakenberger, W. T. Jr. (2002). Ethylene: Agricultural Sources and Applications. Kluwer/Academic Publishers, New York.

Asghar, H. N., Zahir, Z. A., \& Arshad, M. (2004). Screening rhizobacteria for improving the growth, yield, and oil content of canola (Brassica napus L.). Aust. J. Agric. Res., 55, 187194.

Asghar, H. N., Zahir, Z. A., Arshad, M., \& Khaliq, A. (2002). Relationship between in vitro production of auxins by rhizobacteria and their growth promoting activities in Brassica juncea L. Biol. Fertil. Soils, 35, 231-237.

Bent, E., Tuzun, S., Chanway, C. P., \& Enebak, S. (2001). Alterations in plant growth and in root hormone levels of lodgepole pines inoculated with rhizobacteria. Can. J. Microbiol. 47, 793-800. 
Binder, B. M. 2008. The ethylene receptors: Complex perception for a simple gas. Plant Sci., 75, 8-17.

German, M. A., Burdman, S., Okon, Y., \& Kigel, J. (2000). Effects of Azospirillum brasilense on root morphology of common bean (Phaseolus vulgaris L.) under different water regimes. Biol. Fertil. Soils, 32, 259-264.

Glick, B. R., Todorovic, B., Czarny, J., Cheng, Z., Duan, J., \& McConkey, B. (2007). Promotion of plant growth by bacterial ACC deaminase. Crit. Rev.Plant Sci., 26, 227-242.

Jeffries, P., Gianinazzi, S., Perotto, S., Turnau, K., \& Barea, J. M. (2003). The contribution of arbuscular mycorrhizal fungi in sustainable maintenance of plant health and soil fertility. Biol. Fértil. Soils, 37, 1-16.

Kang, B. G., Kim, W. T., Yun, H. S., \& Chang, S. C. (2010). Use of plant growth-promoting rhizobacteria to control stress responses of plant roots. Plant Biotechnol., 4, 179-183

Kanwar, T. S., \& Chopra, S. L. (1959). Practical Agricultural Chemistry. S. Chand and Co., Delhi.

Khalid, A., Arshad, M., \& Zahir, Z. A. (2003). Growth and yield response of wheat to inoculation with auxin producing plant growth promoting rhizobacteria. Pak. J. Bot., 35, 483-498.

Khalid, A., Arshad, M., \& Zahir, Z. A. (2004). Screening plant growth promoting rhizobacteria for improving growth and yield of wheat. J. Appl.Microbiol. 96, 473-480.

Koryo, H. W. (2006). Effect of salinity on growth, photosynthesis and solute composition of the potential cash crop halophyte plantago. Environ. Exp. Bot., 56, 136-146.

Lucy, M., Reed, E., \& Glick, B. R. (2004). Applications of free living plant growth-promoting rhizobacteria. Antonie Leeuwenhoek, 86, 1-25.

Mayak, S., Tirosh, T., \& Glick, B. R. (2004). Plant growth promoting bacteria confer resistance in tomato plants to salt stress. Plant Physiol. Biochem., 42, 565-572.

Nakbanpote, W., Panitlurtumpai, N., Sangdee, A., Sakulpone, N., Sirisom, P., \& Pimthong, A. (2013). Salt-tolerant and plant growth-promoting bacteria isolated from $\mathrm{Zn} / \mathrm{Cd}$ contaminated soil: identification and effect on rice under saline conditions. $J$ Plant Interact., 21, 1-9.

Penrose, D. M., \& Glick, B. R. (2003). Methods for isolating and characterizing ACCdeaminase-containing plant growthpromoting rhizobacteria. Physiol. Plant, 118, 10-15.

Pitman, M. G., \& Läuchli, A. (2002). Global impact of salinity and agricultural ecosystems. Salinity: environment-plantsmolecules, 3, 20.

Ryan, J., Estefan, G., \& Rashid, A. (2001). Soil and Plant Analysis Laboratory Manual. International Center for Agricultural Research in the Dry Areas (ICARDA), Islamabad, Pakistan. 172p.

Salamone, I. E. G. (2000). Direct beneficial effects of cytokinin producing rhizobacteria on plant growth. . Ph.D. Thesis, University of Saskatchewan, Saskatoon, SK Canada.
Selosse, M. A., Baudoin, E., \& Vandenkoornhuyse, P. (2004). Symbiotic microorganisms, a key for ecological success and protection of plants. C. R.Biol. 327, 639-648.

Shaharoona, B., Jamro, G. M., Zahir, Z. A., Arshad, M., \& Memon, K. S. (2007). Effectiveness of various Pseudomonas spp., and Burkholderiacaryophylli containing ACC-deaminase for improving growth and yield of wheat (Triticum aestivum L.). J. Microbiol. Biotechnol. 17, 1300-1307.

Shaharoona, B., Arshad, M., \& Zahir, Z. A. (2006). Effect of plant growth promoting rhizobacteria containing ACCdeaminase on maize (Zea mays L.) growth under axenic conditions and on nodulation in mung bean (Vignaradiata L.). Lett. Appl. Microbiol., 42, 155-159.

Shaharoona, B., Naveed, M., Arshad, M., \& Zahir, Z. A. (2008). Fertilizer dependent efficiency of Pseudomonads for improving growth, yield, and nutrient use efficiency of wheat (Triticum aestivum L.). Appl. Microbiol. Biotechnol. 79, 147155.

Singh, N. K, Chaudhary, F. K., Patel, D. B., \& Triveni, E. (2013) Effectiveness of Azotobacter Bio-Inoculate for Wheat Grown Under Dry Land Condition. Journal of Environmental Biology, 34(5), 927-932.

Sparks, D. L., Carski, T. H., Fendorf, S. E., \& Toner, C.V. (1996). Kinetic methods and measurements. p. 1275-1307. In D.L. Sparks (ed.) Methods of soil analysis: Chemical methods. Soil Science Society of America, Madison, WI.

Stearns,J., \& Glick,,B.,R.,(2003).Transgenic plants with altered ethylene biosynthesis or perception. Biotechnol. Adv. 21, 193-210.

Steel, R. G. D. \& Torrie, J. H. (1997). Principles and Procedure of Statistics. McGraw Hill Book Co., Inc. Singapore, Pp. 173177.

Thrupp, L. A. (2000). Linking agricultural biodiversity and food security: the valuable role of agrobiodiversity for sustainable agriculture. International affairs, 76(2), 283-297.

Wang, W. X., Barak, T., Vinocur, B., Shoseyov, O., \& Altman, A. (2003). Abiotic resistance and chaperones: possible physiological role of SP1, a stable and stabilizing protein from Populus. In Plant Biotechnology 2002 and Beyond (Pp. 439443). Springer Netherlands.

Zahir, Z. A., Arshad, M., \& Frankenberger, W. T., Jr. (2004). Plant growth promoting rhizobacteria: Applications and perspectives in agriculture. Adv.Agron. 81, 97-168. 